\title{
Nutritional Status of Depressive Patients
}

Rym Ben Othman ${ }^{*}$, Olfa Mziou, Amel Gamoudi, Amal Smida, Cyrin Souissi, Insaf Loukil, Feten Mahjoub, Olfa Berriche and Henda Jamoussi National Institute of Nutrition, BAB SAADOUN TUNIS Tunisie, Tunisia

"Corresponding author: Rym Ben Othman, National Institute of Nutrition, BAB SAÂDOUN TUNIS Tunisie, Tunisia, Tel: +21652262806; E-mail: benothmanr@gmail.com

Received date: December 17, 2017; Accepted date: February 17, 2018; Published date: February 28, 2018

Copyright: @ 2018 Othman RB, et al. This is an open-access article distributed under the terms of the Creative Commons Attribution License, which permits unrestricted use, distribution, and reproduction in any medium, provided the original author and source are credited.

\begin{abstract}
Depression is a multifactorial disease and nutrition is an important environmental factor in its development and progression.

Methods: This is a retrospective study of 50 depressed patients recruited from the outpatient department of psychiatry in Tunisia, as well as 50 controls. Both groups were matched for age and sex

Results: A pathological waist circumference was found in $84 \%$ of cases against $78 \%$ of controls $p=0.02$. Our patients had a significantly higher intake of carbohydrates and sucrose compared to controls $p=0.0001, p=0.02$, and significantly lower protein intake $(p=0.0001)$, lipids $(p=0.0001)$, SFA $(p=0.01)$, MUFA $(p=0.003)$, EPA $(p=0.02)$, fibers $(p=0.05)$, iron $(p=0.0001)$, zinc $(p=0.02)$, vitamin B9 $(p=0.0001)$, vitamin B1 $(p=0.02)$ vitamin $C(p=0.02)$, calcium $(P=0.004)$. In addition, controls consumed significantly more blue fish, hard cheeses and Olive oil than the patients respectively. Plus the depression was severe, according to the PHQ9 score, plus the intakes were significantly lower in: proteins, carbohydrates, alpha linoleic acid Calcium, consumption of butter and cheese spread, and when depression was certain, according to the HAD, intakes of protein, w3, alpha linoleic acid, corn oil and soybean were low.
\end{abstract}

Conclusions: Our study revealed a very frequent deficit in micro and macronutrients in depressed patients. Some of these deficits, in particular Omega 3, were significantly associated with the severity of depression.

Keywords: Depression; Nutrition; Omega 3; Omega 6

\section{Introduction}

World health organization (WHO) considers depression as the most frequent psychiatric illness. Indeed, today, 350 million people worldwide are affected by depression [1]. A Tunisian study of psychiatric disorders following the revolution showed that depression was the most prevalent psychiatric disorder with a prevalence of $30.8 \%$ [2].

Depression has a multifactorial origin involving physiological, social, genetic, psychological and environmental factors [3]. Current evidence highlights the crucial role of nutrition as an important environmental factor in the development and progression of depression [2,4-7].

The relationship between diet and depression has been much written, on the one hand diet can be a risk factor for the onset, development and severity of depression, and on the other hand, depression itself can lead to changes in lifestyle [8].

Several authors have noted that deficiency in certain micronutrients such as vitamin B9, vitamin D [4], selenium [5], zinc [6], polyunsaturated fatty acids(PUFA) such as omega 3 [7] and Omega 6 is associated with depression.

The objectives of our study are to evaluate the nutritional status of depressed patients compared to a control group and to detect a possible deficiency in some micro and / or macronutrients in the depressed.

\section{Methods}

This is a retrospective cross-sectional study of 50 depressed patients recruited from the outpatient department of psychiatric hospital in Tunis from November 10 to December 16, 2016, as well as 50 randomized controls with no known psychiatric history, recruited during the same period. Both groups were matched for age and sex.

We included in our study adult patients with depression who were diagnosed by psychiatrists according to the criteria of the DSM IV [9]. In addition, we excluded from our study: pregnant or nursing women, patients with psychiatric disorders other than depression, diabetics, patients on diet or under corticosteroids.

Patients underwent an interrogation concerning their pathology. To assess the depressive state of the patients two scores were used the score hospital anxiety and depression scale" HAD " [10,11] and the patient health questionnaire" PHQ 9 " [12,13].

Anthropometric measurements were taken and were interpreted according to the WHO criteria for BMI and a WC (waist circumference) was pathological if $>80 \mathrm{~cm}$ in women and $94 \mathrm{~cm}$ in men.

The score " MUST ": The Malnutrition Universal Screening Tool (MUST) was also used in our study [14-16]. 
Page 2 of 7

A feeding history was carried out to assess the typical dietary habits of the two groups. This survey details the inputs, meals, snacks, nature and proportion of food consumed. The amount of food was estimated using a photographic manual that the patient used to bring us closer to the portion actually taken [17]. The results of the survey were then analyzed using the computer software "BILNUT, version 2.01-1990" to evaluate the spontaneous nutritional intakes.

A frequency of consumption of certain foods was noted from food history, targeting foods rich in vitamin $\mathrm{D}$, omega 3 and omega 6 . The calculation of omega 3 was split on these different precursors namely EPA (eicosapentaenoic acid), DHA (docosahexaenoic acid) and alpha linolenic acid (Fatty acid C18: 3), the various results were summed in order to obtain the fraction of omega 3 consumed. Similarly for Omega 6 which was calculated based on the alpha linoleic acid intake (Fatty acid C18: 2). These different elements were calculated manually using the food composition table (CIQUAL 2016) [18]. The dietary intake of our population were compared to the recommended nutritional intake RNI of the general adult population [19-21].

The statistical analysis was carried out using statistical software (PSPP) using the Chi-square test for the comparison of qualitative variables and the T-Student test for the comparison of the quantitative ones. We started with a comparative study between the two groups of depressed patients and the control group. The percentages were compared by the Pearson chi-square test, and if this test was invalid, by Fisher's exact bilateral test. The comparison of 2 means was carried out by the Student $t$ test for independent series or by the Mann-Whitney test according to the distribution of the variables. The comparison of 2 averages was carried out by the Student $t$ test for matched series or by the Wilcoxon matched test according to the distribution of the variables. In all cases, the threshold of statistical significance $p$ was set at 0.05 .

\section{Results}

The general characteristics of the population are summarized in Table 1 . The majority (72\%) of the patients had only one episode of depression and $28 \%$ of the patients attempted suicide, $12 \%$ of which were repeated. In our population, only 20 depressed (40\%) reported a psychiatric family history. Our sample consisted of 11 new consultants (22\%) who had not yet been treated, for the rest, $66 \%$ were under antidepressive treatment and $22 \%$ required anxiolytics. For the others, $66 \%$ were on antidepressants and $46 \%$ on anxiolytics.

The mean waist circumference (WC) of the patients was $98.34 \pm 10$ $\mathrm{cm}$ versus $91.77 \pm 18.09 \mathrm{~cm}$ for the controls $(\mathrm{p}=0.02)$. The mean BMI of the patients was $28.21 \pm 6.02 \mathrm{Kg} / \mathrm{m}^{2}$ and that of the controls at 28.10 $\pm 5.15 \mathrm{Kg} / \mathrm{m}^{2}$ (Table 2). In our study, a BMI $>25 \mathrm{Kg} / \mathrm{m}^{2}$ was present in $74 \%$ of the patients versus $69.3 \%$ of the controls $(\mathrm{p}=0.31)$. The weight was higher for almost half of the depressed (52\%) with an average of $8.22 \mathrm{~kg}$ and a maximum of $24 \mathrm{~kg}$. After the diagnosis of depression, weight loss affected $36 \%$ of depressed patients with an average of 7.76 $\mathrm{kg}$ lost. The maximum weight loss was $32 \mathrm{~kg}$. The MUST score did not show a risk of under nutrition in the majority of patients (Figure 1).

\begin{tabular}{|c|c|c|c|c|}
\hline \multicolumn{2}{|l|}{ Variables } & \multirow{2}{*}{$\begin{array}{l}\text { Patients } \\
45.08 \\
14,24\end{array}$} & \multirow{2}{*}{\begin{tabular}{|l|} 
controls \\
$44.72 \quad \pm$ \\
13.2
\end{tabular}} & \multirow{2}{*}{$\begin{array}{l}\mathbf{p}^{*} \\
0.87\end{array}$} \\
\hline $\begin{array}{l}\text { Average age (years) } \\
\pm \text { standard deviation }\end{array}$ & & & & \\
\hline Gender (n) & & $\begin{array}{l}\text { Females: } 34 \\
\text { Males : } 16\end{array}$ & $\begin{array}{l}\text { Females } \\
33 \\
\text { Males: } 17\end{array}$ & 0.83 \\
\hline \multirow[b]{5}{*}{$\begin{array}{l}\text { Level of education } \\
\text { (\%) }\end{array}$} & Illiterate & 16 & 6 & \\
\hline & Primary level & 40 & 6 & \\
\hline & Secondary level & 32 & 48 & \\
\hline & Higher level & 10 & 38 & 0.0001 \\
\hline & $\begin{array}{l}\text { Professional } \\
\text { training }\end{array}$ & 2 & 2 & \\
\hline \multirow[b]{4}{*}{ Marital status (\%) } & Single & 18 & 18 & \\
\hline & Married & 68 & 76 & 0.48 \\
\hline & Divorced & 6 & 0 & \\
\hline & Widower & 8 & 6 & \\
\hline \multirow[b]{5}{*}{ Profession (\%) } & Unemployment & 34 & 22 & \\
\hline & Student & 2 & 6 & \\
\hline & Official & 50 & 70 & 0.03 \\
\hline & Daily & 2 & 2 & \\
\hline & retirement & 2 & 0 & \\
\hline Clothing habits (\%) & Headscarf & 83 & 58 & 0.02 \\
\hline \multirow[b]{2}{*}{ Women's Cycle (n) } & Regular & 9 & 22 & 0.01 \\
\hline & Menopause (n) & 17 & 10 & 0.37 \\
\hline \multirow[b]{3}{*}{ Physical activity (\%) } & low & 66 & 34 & \\
\hline & average & 34 & 62 & 0.001 \\
\hline & Intense & 0 & 4 & \\
\hline \multicolumn{2}{|c|}{ Duration of exposition to the sun (min) } & 38.20 & 46.5 & 0.29 \\
\hline \multicolumn{2}{|l|}{ Tabacco (\%) } & 66 & 34 & 0.001 \\
\hline \multicolumn{2}{|l|}{ Alcool (\%) } & 14 & 0 & 0.006 \\
\hline \multicolumn{2}{|l|}{ Drugs (n) } & 3 & 0 & 0.08 \\
\hline
\end{tabular}

Table 1: Distribution of the population according to its general characteristics.

\begin{tabular}{|l|l|l|l|l|}
\hline & \multicolumn{2}{l|}{ Depressed } & \multicolumn{2}{l|}{ controls } \\
\cline { 2 - 5 } & $\mathbf{n}$ & $\%$ & $\mathbf{n}$ & $\%$ \\
\hline Underutrition class 2 & 1 & 2 & 0 & 0 \\
\hline Normal corpulence & 12 & 24 & 15 & 30 \\
\hline Overweight & 18 & 36 & 18 & 36 \\
\hline Obesity Class 1 & 14 & 28 & 10 & 20 \\
\hline Obesity Class 2 & 3 & 6 & 6 & 12 \\
\hline Obesity Class 3 & 2 & 4 & 1 & 2 \\
\hline
\end{tabular}

Table 2: Distribution of population by body mass index (BMI). 
Citation: Othman RB, Mziou O, Gamoudi A, Smida A, Souissi C, et al. (2018) Nutritional Status of Depressive Patients. J Diabetes Metab 9: 786.

Page 3 of 7

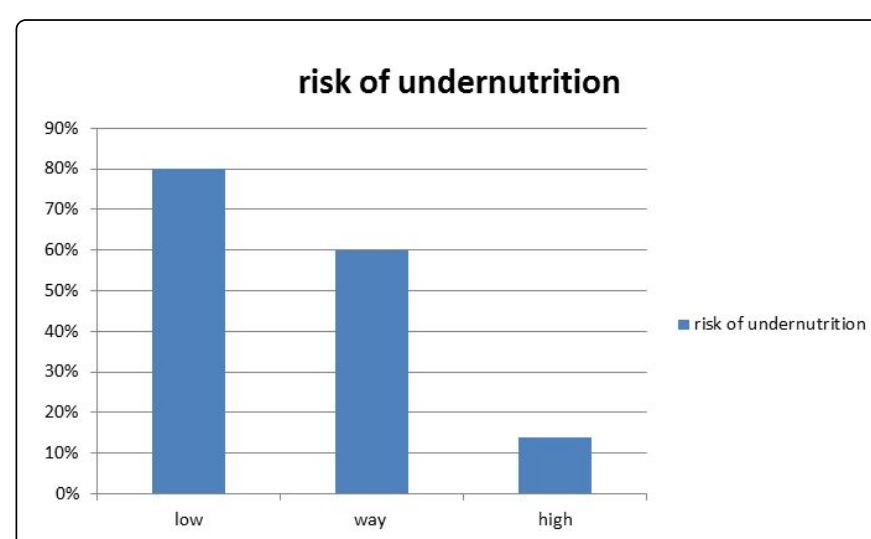

Figure 1: Distribution of patients according to the MUST score.

For the patients, a pathological WC was found in $84 \%$ of the cases against $78 \%$ of the controls. Depressed men had significantly more abdominal obesity than controls ( $18 \%$ versus $14 \%)(\mathrm{p}=0.001)$.

The results of the food surveys are summarized in Tables 3-7 and Figures 2 and 3.

\begin{tabular}{|l|l|l|l|}
\hline & Patients & Controls & $\mathbf{p}$ \\
\hline \multirow{2}{*}{ Average caloric intake (Kcal/d) } & 1985.34 & 2186.5 & 0.19 \\
\cline { 2 - 4 } & 2387.94 & 2162.06 & \\
\hline Carbohydrate (\% TEl) & 52.79 & 44.65 & 0.0001 \\
\hline Sucrose (\% TEl) & 11.52 & 8.61 & 0.02 \\
\hline Total proteins (g/kg iw /d) * & 0.86 & 1.19 & 0.0001 \\
\hline Protein (\% TEI) & 11.19 & 13.75 & 0.0001 \\
\hline Lipids (\% TEI) & 36.05 & 41.37 & 0.0001 \\
\hline SFA (\% Lipids) & 8.88 & 10.16 & 0.01 \\
\hline MUFA (\% Lipids) & 15.62 & 18.82 & 0,003 \\
\hline PUFA (\% lipids) & 11.52 & 12.38 & 0.32 \\
\hline $\begin{array}{l}\text { Cholesterol (mg/day) } \\
\text { *iw: ideal weight; TEl= total energy } \\
\text { MUFA=monounsattured fatty acid }\end{array}$ & 191.48 & 294.42 & 0.1 \\
\hline
\end{tabular}

Table 3: Average Intakes of Calories and Macronutrients.

\begin{tabular}{|l|l|l|l|}
\hline & patients & controls & $\mathbf{P}$ * \\
\hline Alpha linolenic acid (g / d) & $2,5 \pm 1,71$ & $2,44 \pm 2,88$ & 0.9 \\
\hline EPA (mg / day) & $12 \pm 0,21$ & $24 \pm 0,33$ & 0.02 \\
\hline DHA (mg / day) & $19 \pm 0,29$ & $30 \pm 0,37$ & 0.09 \\
\hline Omega 3 (\% TEl) & $1,34 \pm 0,78$ & $1,09 \pm 0,7$ & 0.76 \\
\hline Omega 6 (\% TEl) & $9,5 \pm 4,73$ & $10,39 \pm 3,77$ & 0.3 \\
\hline
\end{tabular}

Table 4: Mean fatty acid intake.

\begin{tabular}{|c|c|c|c|}
\hline & Patient & Controls & $\mathbf{P}$ * \\
\hline Fibers (g / d) & 13,43 & 16.57 & 0.05 \\
\hline Iron (mg / day) & $\begin{array}{l}7.16 \\
8.74\end{array}$ & $\begin{array}{l}10.53 \\
10.48\end{array}$ & 0.0001 \\
\hline Magnesium (mg / day) & $\begin{array}{l}254.96 \\
285.06\end{array}$ & $\begin{array}{l}263.34 \\
262.18\end{array}$ & 0.75 \\
\hline Zinc (mg / d) & 5.76 & 7.06 & 0.02 \\
\hline Folic acid $(\mu \mathrm{g} / \mathrm{d})$ & $\begin{array}{l}148.98 \\
153.69\end{array}$ & $\begin{array}{l}228.92 \\
232.18\end{array}$ & 0.0001 \\
\hline Vitamin B1 $(\mathrm{mg} / \mathrm{d})$ & 0.73 & 0.92 & 0.02 \\
\hline Vitamin C $(\mathrm{mg} / \mathrm{d})$ & 65.34 & 115.94 & 0.02 \\
\hline Phosphorus (mg / d) & 817.7 & 1129.96 & 0,001 \\
\hline Potassium (mg / d) & 2010.1 & 2393.64 & 0.03 \\
\hline Calcium (mg / day) & $\begin{array}{l}568.22 \\
578.81\end{array}$ & $\begin{array}{l}756.94 \\
749.88\end{array}$ & 0,004 \\
\hline Vitamin D $(\mu \mathrm{g} / \mathrm{d})$ & 2.55 & 3.03 & 0.27 \\
\hline Sodium (mg / day) & 1102.94 & 1290.62 & 0.12 \\
\hline Water $(\mathrm{ml} / \mathrm{d})$ & 1010 & 1100 & 0.41 \\
\hline
\end{tabular}

Table 5: Mean Intakes of Micronutrients and Dietary Fiber.

\begin{tabular}{|l|l|l|l|}
\hline (Number of servings per week) & patients & controls & P \\
\hline Blue fish & 0.9 & 1.7 & 0.02 \\
\hline Hard cheese & 0.38 & 1.22 & 0,009 \\
\hline Yogurt & 2.1 & 1.92 & 0.72 \\
\hline eggs & 4.56 & 5.64 & 0.06 \\
\hline Olive oil & 2.38 & 4.42 & 0,001 \\
\hline Corn oil & 1.54 & 3.64 & 0,002 \\
\hline
\end{tabular}

Table 6: Comparison of the frequency of weekly consumption of certain foods in our population.

\begin{tabular}{|l|l|l|l|l|}
\hline & $\begin{array}{l}\text { Absence of } \\
\text { symptomatolog } \\
\text { y }\end{array}$ & $\begin{array}{l}\text { Symptomatolog } \\
\text { y doubtful }\end{array}$ & $\begin{array}{l}\text { Symptomatolog } \\
\text { y certain }\end{array}$ & P * \\
\hline BMI (kg / m²) & 34.81 & 25.416 & 27.76 & 0.01 \\
\hline Protein (g/d) & 6052 & 52.27 & 48.76 & 0.03 \\
\hline W3 (g/d) & 37 & 3.9 & 2.3 & 0.03 \\
\hline $\begin{array}{l}\text { Alpha linoleic } \\
\text { acid (g/d) }\end{array}$ & 37.39 & 22.66 & 18.46 & 0,002 \\
\hline $\begin{array}{l}\text { Corn oil (ml / } \\
\text { week) }\end{array}$ & 149.8 & 0 & 41.1 & 0.03 \\
\hline $\begin{array}{l}\text { Soybean oil } \\
\text { (ml / week) }\end{array}$ & 261.4 & 838.5 & 150.36 & 0,009 \\
\hline
\end{tabular}

Table 7: Association between nutritional profile and HAD score. 


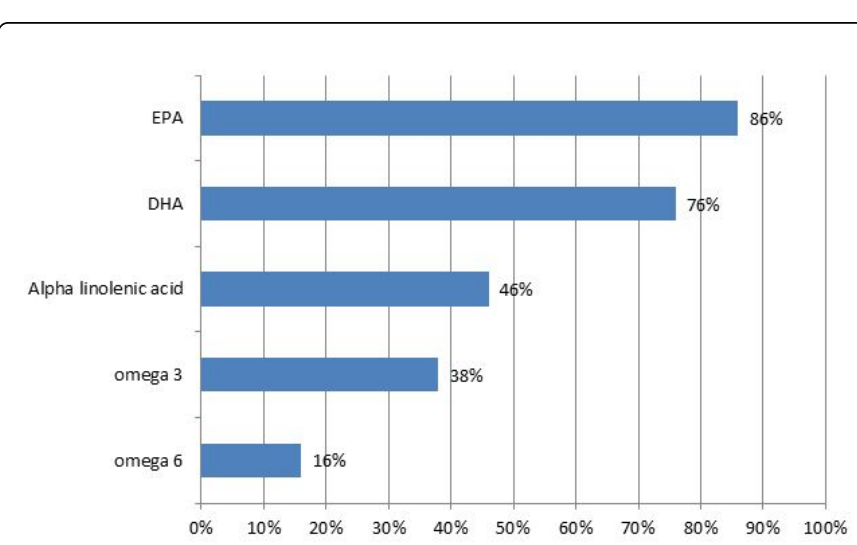

Figure 2: Percentage of patients with insufficient intake of essential fatty acids by daily energy intake $[18,19]$.

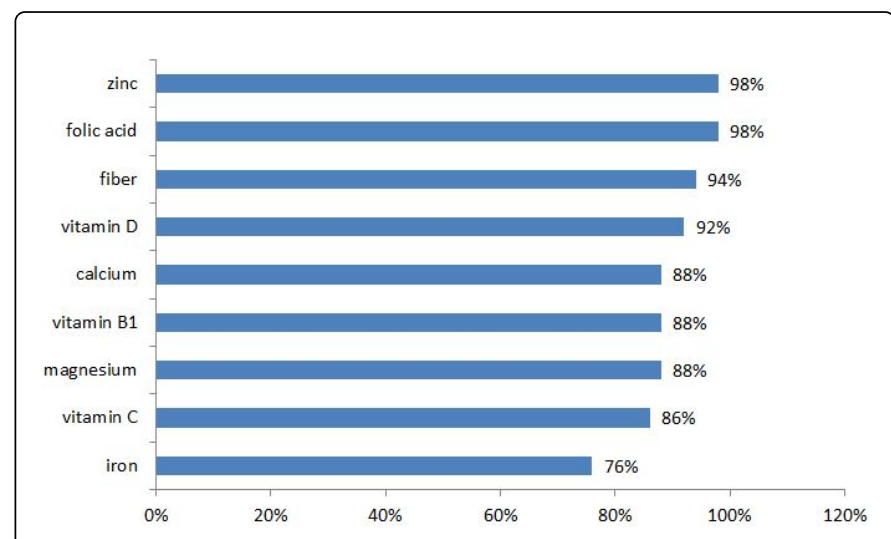

Figure 3: Percentage of patients with insufficient intake of micronutrients by Daily energy intake.

The majority of patients (72\%) were taking vitamin $\mathrm{E}$ and iron supplements but the difference was not significant with controls $(\mathrm{p}=0.26)$.

The association between the severity of the depression sought by the HAD scores and the food survey results was noted in Table 7.

The more severe the depression, according to the PHQ9 score, the significantly lower the intakes of protein, carbohydrates, alpha linoleic acid, calcium, consumption of butter and spread, respectively $\mathrm{p}=0.03$; $0.01 ; 0.04 ; 0.02 ; 0.004$ and 0.005 . The rest of the nutritional parameters did not show any significant results with PHQ-9.

There were no differences between the macro and micronutrients intake of the patients according to their treatment or between the patients already treated and the newest one.

\section{Discussion}

The mean WC of the patients was significantly higher than the controls $(p=0.02)$. Our results were consistent with those of Correia et al. [22] who found that $69 \%$ of depressed patients had waist circumference above normal values. Zhao et al. [23] found that in overweight or obese adults, abdominal obesity was significantly associated with an increased likelihood of having severe depressive symptoms. The cohort of Lasserre et al. [24] who followed 3054 participants for 5.5 years showed that only patients with depression increased their waist size during follow-up. However, other studies have found contradictory results, notably those of Turley [25] and Hach [26] who did not find significant relationships between a high waist circumference and depression.

The protein intake in patients was $0.86 \mathrm{~g} / \mathrm{kg}$ ideal weight per day, i.e. $55.53 \mathrm{~g} /$ day. This was significantly lower than that of controls $(\mathrm{p}=0.0001)$. In our study, $66 \%$ of our patients were protein-deficient, in contrast to the Pourghassem study where $11.4 \%$ of patients had insufficient protein intake [27]. Some studies agree that amino acids (tryptophan, phenylalanine, tyrosine and methionine) are useful in the treatment of many mental disorders such as depression [28,29], since some essential amino acids are involved in the synthesis of Neurotransmitters and neuro-modulators [30]. Tryptophan even improves the quality of sleep $[28,31]$.

Patients' carbohydrate intake was $52.79 \%$ of the total energy intake (TEI). These intakes estimated at $249.91 \mathrm{~g} /$ day were significantly greater than controls $(\mathrm{p}=0.0001)$. Our results are comparable to Gülşah Kaner [32] and Ben Smail [33]. In Iran, a contribution of $318.6 \mathrm{~g} / \mathrm{d}$ was found in the study of Pourghassem Gargari [27], whose purpose was to determine the relationship between nutrient intake and the severity of depression. The consumption of carbohydrates increases the release of serotonin, involved in several functions such as sleep, pain sensitivity and mood control [34-36]. As a result, many patients have an appetite for carbohydrates after major depressive episodes [37].

The daily intake of PUFA patients and controls was well below the recommendations with a non-significant difference between the two groups. Several studies have demonstrated the benefits of PUFA supplementation for depression $[38,39]$. Notably the study by Venna et al. [40]. Where supplementation of PUFA had an antidepressant effect that was explained by molecular changes at the hippocampus.

The majority of our patients (82\%) had lower intakes of cholesterol compared to recommended dietary intakes. Different physiopathological explanations have been given, in particular, that a low cholesterol level could negatively affect the mood by a direct effect on the serotonin system [41]. Others have explained the association between depression and cholesterol levels by the fact that it has an essential role in the structure and functioning of the cell membrane and can also affect neurotransmission, thus cholesterol deficiency In neuronal membranes may also have a direct impact on dendritic growth [42], synapses [43] and even neuronal survival [44]. On the other hand, other studies [45-47] refuted these explanations.

In our study, the majority of patients had inadequate intake of EPA (86\%), and they consumed significantly less EPA than controls $(p=0.02)$. Numerous studies have examined the beneficial effect of EPA on depression: the study by Demosthenes et al. [48] among 453 men and 400 women showed that elevated plasma EPA concentrations were associated with low depression. Martin [49] conducted a meta-analysis examining the effect of omega-3 supplementation on depression. He showed that EPA may be more effective than DHA in treating depression. As an important membrane component, EPAs have beneficial effects on the brain by modulating the neuroimmune and apoptotic pathways, modifying membrane function and competing with omega 6 , precursors of inflammatory mediators [50].

In our patients, we observed a deficiency of alpha linolenic acid (46\%), and omega 3 (38\%). Their intakes were lower than the controls but the results were not statistically significant. These results are 
Page 5 of 7

similar to the study by Hakkarainen et al. [51] performed on 29,133 men aged 50-69 who found that there was no association between dietary intake of omega-3 fatty acids, Depressed mood and major depressive episodes. Indeed, the relationship between omega 3 and depression has been the subject of several studies [52,53]. A metaanalysis of the effects of omega 3 on depression concluded that there was evidence of the effect of omega 3 on mood [54,55]. The results of the study by Rees et al. [56] showed that women with low omega-3 intakes were six times more likely to develop perinatal depression than women with adequate omega-3 intakes. A prospective study from 54,662 American women from 1996 to 2006 demonstrated that $\alpha$ linolenic acid (ALA) intake was inversely associated with the risk of depression [57].

The mean intake of zinc in our patients was significantly lower than the controls $(\mathrm{p}=0.02)$ with $98 \%$ of the patients with a deficiency of intake. The study of Styczen al [6] carried out in 2017 showed that serum zinc levels in patients with depressive episodes were significantly lower than those in controls $(p=0.003)$. Zinc is the most concentrated trace element in the brain, especially in the hippocampus and cerebral cortex. It contributes to the structure of the nervous system and contributes to the proper functioning of the brain. Zinc deficiency can influence cerebral homeostasis and can lead to impaired behavior and mental functions [58]. Many studies have shown that in depression there is an imbalance between the main excitatory systems (Glutaminergic) and inhibitors (GABA) and administration of antagonists of the glutaminergic system, including zinc, has shown antidepressant effect in clinical studies [59].

The average intake of folic acid in patients was significantly lower than the control with a deficiency of intake which affected $98 \%$ of the patients. A study of 9670 participants showed that low folate intake was associated with depression [60]. In fact, folate deficiency was associated with low levels of 5-hydroxyindoleacetic acid (5-HIAA), a metabolite of serotonin, in the cerebrospinal fluid [61]

Our results showed that patients had a significantly lower calcium intake than controls and $88 \%$ of them don't meet their needs. The more severe the depression was according to the phq9 and the calcium intakes were low. Calcium activates the enzyme tryptophan hydroxylase which intervenes in the metabolic pathways of serotonin synthesis [62].

The mean iron intake of the patients was significantly lower than the controls. Inadequate intake was found in $76 \%$ of patients. Iron plays an important role in the oxygenation of the brain parenchyma, the synthesis of several neurotransmitters such as dopamine and serotonin as well as enzymes of the nervous system, namely tyrosine hydroxylase and tryptophan hydroxylase [63].

Mean intake of vitamin B1 in patients was significantly lower than in controls $(\mathrm{p}=0.02)$, an inadequate intake was found in $88 \%$ of patients. Zhang et al. [64] found that lower thrombocytopenia levels of thiamine (free thiamine, thiamine mono phosphate (TMP), and thiamine di phosphate (TDP)) were associated with a higher prevalence of depressive symptoms. Thiamine di phosphate (TDP), the most bioactive form of thiamine, is a coenzyme in glucose metabolism crucial for secretion of serotonin [65].

The consumption of blue fish was significantly higher in controls than in patients. A meta-analysis by Li et al. [66] showed that high consumption of fish could reduce the risk of depression. Several studies have shown an inverse relationship between fish consumption and depression, as many other studies [67-70]. In the cross-sectional study of Smith et al. [71] conducted from 2009 to 2011, consumption of fish was examined continuously using a frequency questionnaire: women who ate fish $\geq 2$ times / week at the start of the study had a $25 \%$ lower risk of depression than those who ate fish $<2$ times / week. Fish is an important source of PUFA (omega 3). Parletta et al. [72] have shown that omega-3 play an important role in the growth of axons, increase the fluidity and flexibility of the brain's cell membrane, improve the function of neurotransmitters such as serotonin and dopamine. They play an important role in the endothelial function, they increase the transport of glucose, they promote the synthesis of neuroprotectin D1 (NDP1) and therefore a large fish intake can thus prevent depression.

The intake of hard cheeses was higher in controls ( $\geq 1$ time / week) than in patients $(<1$ time/week). Different studies have suggested that high dairy consumption is associated with better brain function and mood [73], cheese consumption was associated with a lower prevalence of cognitive deficit [74] despite their low PUFA and MUFA content. Changes in the extracellular concentration of calcium can affect the excitability of cells involved in the emotional regulation [75] and thus a correct intake of cheese, an important source of calcium, can be protective against these changes.

According to our study, patients consumed less olive oil than controls. Reverse associations between depression and the Mediterranean diet (rich in olive oil) have been demonstrated in several studies [76,77]. In the prospective study of kyrozis et al. [78] spreading over 13 years, the depression score was negatively associated with food intake of MUFA and their main source theolive oil. This has been justified in other studies by the fact that this consumption could improve the binding of serotonin to its receptors [79]. In addition to these antioxidant properties, olive oil increases and maintains the activity of the stearyl-CoA 9-desaturase enzyme, or $\Delta 9$-desaturase (whose activity allows to pass from stearic acid, saturated, To oleic acid), and thus maintains the physicochemical properties of neuronal membranes [80].

However, there are some limitations to our study: this is a retrospective study that involved a small sample from which the causal link is difficult to establish, and we were not able to perform biological investigations.

\section{Conclusion}

Our study has highlighted severe reduced intake in micronutrient $s$ that are certainly related to the installation of depression and its potential gravity.

Therefore, the imperative of nutritional care for depressed patients associated with psychiatric care is of crucial importance. These aspects are completely ignored in the treatment of depressed patients. These patients should be advised of the nutritional dimension of their pathology and thus adopt a healthy lifestyle with adequate diet and regular physical activity to effectively prevent and treat overweight or obesity and metabolic comorbidity.

This management will allow regular monitoring of anthropometric measurements to avoid weight gain and will involve a nutritional evaluation to detect deficiencies and/or excess intake of macro and micronutrients which may aggravate the symptomatology of depression. 


\section{References}

1. WHO (2017) Depression. WHO.

2. Christensen L (1996) Nutrition and depression. In: Diet-behavior relationships: Focus on depression. American Psychological Association Pp: 89-108.

3. Won MS, Kim S, Yang YJ (2016) Comparison of Health Status and Nutrient Intake between Depressed Women and Non-depressed Women: Based on the 2013 Korea National Health and Nutrition Examination Survey. Clin Nutr Res 5: 112-125.

4. Parker GB, Brotchie H, Graham RK (2017) Vitamin D and depression. See comment in PubMed Commons below J Affect Disord 208: 56-61.

5. Pasco JA, Jacka FN, Williams LJ, Evans-Cleverdon M, Brennan SL, et al. (2012) Dietary selenium and major depression: a nested case-control study. Complement Ther Med 20: 119-123.

6. Styczen K, Sowa-Kucma M, Siwek M, Dudek D, Reczynski W, et al. (2017) The serum zinc concentration as a potential biological marker in patients with major depressive disorder. Metab Brain Dis 32: 97-103.

7. Meyer BJ, Kolanu N, Griffiths DA, Grounds B, Howe PRC, et al. (2013) Food groups and fatty acids associated with self-reported depression: an analysis from the Australian National Nutrition and Health Surveys. Nutrition 29: 1042-1047.

8. Jacka FN, Cherbuin N, Anstey KJ, Butterworth P (2015) Does reverse causality explain the relationship between diet and depression? J Affect Disord 175: 248-250.

9. Allen Frances (2012) Manuel Diagnostique Et Statistique Des Troubles Mentaux.

10. Alamri Y (2017) The Arabic Hospital Anxiety and Depression Scale. See comment in PubMed Commons below Chron Respir Dis 14: 100-101.

11. Malasi TH, Mirza IA, el-Islam MF (1991) Validation of the Hospital Anxiety and Depression Scale in Arab patients. See comment in PubMed Commons below Acta Psychiatr Scand 84: 323-326.

12. Arrieta J, Aguerrebere M, Raviola G, Flores H, Elliott P, et al. (2017) Validity and Utility of the Patient Health Questionnaire (PHQ)-2 and PHQ-9 for Screening and Diagnosis of Depression in Rural Chiapas, Mexico: A Cross-Sectional Study. J Clin Psychol. sept 73: 1076-1090.

13. Kroenke K, Spitzer RL, Williams JB (2001) The PHQ-9: validity of a brief depression severity measure. J Gen Intern Med 16: 606-613.

14. Boléo-Tomé C1, Monteiro-Grillo I, Camilo M, Ravasco P (2012) Validation of the Malnutrition Universal Screening Tool (MUST) in cancer. See comment in PubMed Commons below Br J Nutr 108: 343-348.

15. Karsegard VL, Ferlay O, Maisonneuve N, Kyle UG, Dupertuis YM, et al. (2004) Simplified malnutrition screening tool: Malnutrition Universal Screening Tool (MUST). Rev Med Suisse Romande 124: 601-605.

16. Stratton RJ, Hackston A, Longmore D, Dixon R, Price S, et al. (2004) Malnutrition in hospital outpatients and inpatients: prevalence, concurrent validity and ease of use of the 'malnutrition universal screening tool' (MUST) for adults. Br J Nutr 92: 799-808.

17. Bouchoucha M, Akrout M, Bellali H, Bouchoucha R, Tarhouni F, et al. (2016) Development and validation of a food photography manual, as a tool for estimation of food portion size in epidemiological dietary surveys in Tunisia. Libyan J Med 11: 32676.

18. Anses (2017) Table Ciqual 2016 Composition nutritionnelle des aliments.

19. Anses-Agence nationale de sécurité sanitaire de l'alimentation, de lenvironnement et du travail.

20. OMS (2017) Organisation mondiale de la Santé. WHO.

21. Jean-Michel Lecerf, Jean-Louis Schlienger. Nutrition Préventive Et Thérapeutique. 2016.

22. Correia J, Ravasco P1 (2014) Weight changes in Portuguese patients with depression: which factors are involved? See comment in PubMed Commons below Nutr J 13: 117.

23. Zhao G, Ford ES, Li C, Tsai J, Dhingra S, Balluz LS (2011) Waist circumference, abdominal obesity, and depression among overweight and obese U.S. adults: National Health and Nutrition Examination Survey 2005-2006. BMC Psychiatry 11:130.

24. Lasserre AM, Glaus J, Vandeleur CL, Marques-Vidal P, Vaucher J, et al. (2014) Depression With Atypical Features and Increase in Obesity, Body Mass Index, Waist Circumference, and Fat Mass: A Prospective, Population-Based Study. JAMA Psychiatry 71: 880-888.

25. Turley M, Tobias M, Paul S (2006) Non-fatal disease burden associated with excess body mass index and waist circumference in New Zealand adults. Aust N Z J Public Health. 30: 231-237.

26. Hach I, Ruhl UE, Klotsche J, Klose M, Jacobi F (2006) Associations between waist circumference and depressive disorders. J Affect Disord 92: 305-308.

27. Pourghassem Gargari B, Saboktakin M, Mahboob S, Pourafkari N (2012) Nutritional Status in Patients with Major Depressive Disorders: A Pilot Study in Tabriz, Iran. Health Promot Perspect 2: 145-152.

28. Rao TS, Asha MR, Ramesh BN, Rao KS (2008) Understanding nutrition, depression and mental illnesses. Indian J Psychiatry 50: 77-82.

29. Rajagopal S, Sangam SR, Singh S, Joginapally VR (2016) Modulatory Effects of Dietary Amino Acids on Neurodegenerative Diseases. See comment in PubMed Commons below Adv Neurobiol 12: 401-414.

30. Bourre JM (2006) Effects of nutrients (in food) on the structure and function of the nervous system: update on dietary requirements for brain. Part 2? macronutrients. J Nutr Health Aging 10: 386-399.

31. Lieberman HR, Agarwal S, Fulgoni VL (2016) Tryptophan Intake in the US Adult Population Is Not Related to Liver or Kidney Function but Is Associated with Depression and Sleep Outcomes. J Nutr 146: 2609S-2615S.

32. Kaner G, Soylu M, Yüksel N, Inanç N, Ongan D, et al. (2015) Evaluation of Nutritional Status of Patients with Depression. BioMed Res Int 2015: 521481.

33. Ben Smail Salma (2013) etude comparative du comportement alimentaire entre deux groupes de femmes dépressives et non dépressives. Projet de fin détudes.

34. Wurtman RJ, Wurtman JJ (1995) Brain serotonin, carbohydrate-craving, obesity and depression. Obes Res 4: 477S-480S.

35. Wurtman JJ (1990) Carbohydrate craving. Relationship between carbohydrate intake and disorders of mood. Drugs 3: 49-52.

36. Møller SE (1992) Serotonin, carbohydrates, and atypical depression. Pharmacol Toxicol 1: 61-71.

37. Wurtman JJ (1993) Depression and weight gain: the serotonin connection. J Affect Disord 29: 183-192.

38. Park Y, Park YS, Kim SH, Oh DH, Park YC (2015) Supplementation of n-3 Polyunsaturated Fatty Acids for Major Depressive Disorder: A Randomized, Double-Blind, 12-Week, Placebo-Controlled Trial in Korea. Ann Nutr Metab 66: 141-148.

39. Chhetry BT, Hezghia A, Miller JM, Lee S, Rubin-Falcone H, et al. (2016) Omega-3 polyunsaturated fatty acid supplementation and white matter changes in major depression. J Psychiatr Res 75: 65-74.

40. Venna VR, Deplanque D, Allet C, Belarbi K, Hamdane M, et al. (2009) PUFA induce antidepressant-like effects in parallel to structural and molecular changes in the hippocampus. Psychoneuroendocrinology 34 : 199-211.

41. Hawthon K, Cowen P, Owens D, Bond A, Elliott M (1993) Low serum cholesterol and suicide. Br J Psychiatry 162: 818-825.

42. Fan QW, Yu W, Gong JS, Zou K, Sawamura N, et al. (2002) Cholesteroldependent modulation of dendrite outgrowth and microtubule stability in cultured neurons. J Neurochem 80: 178-190.

43. Mauch DH, Nägler K, Schumacher S, Göritz C, Müller EC, et al. (2001) CNS synaptogenesis promoted by glia-derived cholesterol. Science 94 : 1354-1357.

44. Michikawa M, Yanagisawa K (1999) Inhibition of cholesterol production but not of nonsterol isoprenoid products induces neuronal cell death. J Neurochem 72: 2278-2285.

45. Hibbeln JR, Salem N (1995) Dietary polyunsaturated fatty acids and depression: when cholesterol does not satisfy. Am J Clin Nutr 62: 1-9. 
46. Bartoli F, Crocamo C, Dakanalis A, Riboldi I, Miotto A, et al. (2016) Association between total serum cholesterol and suicide attempts in subjects with major depressive disorder: Exploring the role of clinical and biochemical confounding factors. Clin Biochem.

47. Brunner J, Parhofer KG, Schwandt P, Bronisch T (2002) Cholesterol, essential fatty acids, and suicide. See comment in PubMed Commons below Pharmacopsychiatry 35: 1-5.

48. Panagiotakos DB, Mamplekou E, Pitsavos C, Kalogeropoulos N, Kastorini C-M, et al. (2010) Fatty Acids Intake and Depressive Symptomatology in a Greek Sample: An Epidemiological Analysis. J Am Coll Nutr 29: 586-594.

49. Martins JG (2009) EPA but Not DHA Appears To Be Responsible for the Efficacy of Omega-3 Long Chain Polyunsaturated Fatty Acid Supplementation in Depression: Evidence from a Meta-Analysis of Randomized Controlled Trials. J Am Coll Nutr 28: 525-542.

50. Song C, Shieh CH, Wu YS, Kalueff A, Gaikwad S, et al. (2016) The role of omega-3 polyunsaturated fatty acids eicosapentaenoic and docosahexaenoic acids in the treatment of major depression and Alzheimer's disease: Acting separately or synergistically? Prog Lipid Res 62: 41-54.

51. Hakkarainen R1, Partonen T, Haukka J, Virtamo J, Albanes D, et al. (2004) Is low dietary intake of omega-3 fatty acids associated with depression? See comment in PubMed Commons below Am J Psychiatry 161: 567-569.

52. Frasure-Smith N, Lespérance F, Julien P (2004) Major depression is associated with lower omega-3 fatty acid levels in patients with recent acute coronary syndromes. Biol Psychiatry 55: 891-896.

53. Schins A, Crijns HJ, Brummer RJM, Wichers M, Lousberg R, et al. (2007) Altered omega-3 polyunsaturated fatty acid status in depressed postmyocardial infarction patients. Acta Psychiatr Scand 115: 35-40.

54. Beydoun MA, Fanelli Kuczmarski MT, Beydoun HA, Hibbeln JR, Evans $\mathrm{MK}$, et al. (2013) ?-3 fatty acid intakes are inversely related to elevated depressive symptoms among United States women. J Nutr 143: 1743-1752.

55. Su KP, Huang SY, Chiu CC, Shen WW (2003) Omega-3 fatty acids in major depressive disorder. A preliminary double-blind, placebocontrolled trial. Eur Neuropsychopharmacol 13: 267-271.

56. Rees AM, Austin MP, Owen C, Parker G (2009) Omega-3 deficiency associated with perinatal depression: Case control study. Psychiatry Res 166: 254-259.

57. Lucas M, Mirzaei F, O’Reilly EJ, Pan A, Willett WC, et al. (2011) Dietary intake of n-3 and n- 6 fatty acids and the risk of clinical depression in women: a 10-y prospective follow-up study. Am J Clin Nutr 93: 1337-1343.

58. Takeda A (2000) Movement of zinc and its functional significance in the brain. Brain Res Rev34:137-148.

59. Mlyniec K (2015) Zinc in the Glutamatergic Theory of Depression. See comment in PubMed Commons below Curr Neuropharmacol 13: 505-513.

60. Sánchez-Villegas A, Doreste J, Schlatter J, Pla J, Bes-Rastrollo M, et al. (2009) Association between folate, vitamin B6 and vitamin B12 intake and depression in the SUN cohort study. J Hum Nutr Diet 22: 122-133.

61. Botez MI, Young SN, Bachevalier J, Gauthier S (1982) Effect of folic acid and vitamin B12 deficiencies on 5-hydroxyindoleacetic acid in human cerebrspinal fluid. Ann Neurol 12: 479-484.
62. Knapp S, Mandell AJ, Bullard WP (1975) Calcium activation of brain tryptophan hydroxylase. Life Sci 16: 1583-1593.

63. Beard JL, Connor JR, Jones BC (1993) Iron in the brain. Nutr Rev 51: 157-170.

64. Zhang G, Ding H, Chen H, Ye X, Li H, et al. (2013) Thiamine nutritional status and depressive symptoms are inversely associated among older Chinese adults. J Nutr 143:53-58.

65. Wurtman RJ, Wurtman JJ (1995) Brain Serotonin, CarbohydrateCraving, Obesity and Depression. Obes Res 3: 477S-480S.

66. Li F1, Liu X, Zhang D (2016) Fish consumption and risk of depression: a meta-analysis. See comment in PubMed Commons below J Epidemiol Community Health 70: 299-304.

67. Tanskanen A, Hibbeln JR, Tuomilehto J, Uutela A, Haukkala A, et al. (2001) Fish consumption and depressive symptoms in the general population in Finland. Psychiatr Serv Wash DC 52: 529-531.

68. Suominen-Taipale AL, Partonen T, Turunen AW, Männistö S, Jula A, et al. (2010) Fish consumption and omega-3 polyunsaturated fatty acids in relation to depressive episodes: a cross-sectional analysis. PloS One 5: e10530.

69. Yoshikawa E, Nishi D, Matsuoka Y (2015) Fish consumption and resilience to depression in Japanese company workers: a cross-sectional study. Lipids Health Dis 14: 51.

70. Li Y, Dai Q, Ekperi LI, Dehal A, Zhang J (2011) Fish consumption and severely depressed mood, findings from the first national nutrition follow-up study. Psychiatry Res 190: 103-109.

71. Smith KJ, Sanderson K, McNaughton SA, Gall SL, Dwyer T, et al. (2014) Longitudinal associations between fish consumption and depression in young adults. Am J Epidemiol 179: 1228-1235.

72. Parletta N, Milte CM, Meyer BJ (2013) Nutritional modulation of cognitive function and mental health. See comment in PubMed Commons below J Nutr Biochem 24: 725-743.

73. Camfield DA, Owen L, Scholey AB, Pipingas A, Stough C (2011) Dairy constituents and neurocognitive health in ageing. See comment in PubMed Commons below Br J Nutr 106: 159-174.

74. Rahman A, Sawyer BP, Allman RM, Zamrini E (2007) Dietary factors and cognitive impairment in community-dwelling elderly. J Nutr Health Aging 11: 49-54.

75. Bae YJ, Kim SK (2012) Low dietary calcium is associated with self-rated depression in middle-aged Korean women. Nutr Res Pract 6: 527-533.

76. Adjibade M, Assmann KE, Andreeva VA, Lemogne C, Hercberg S, et al. (2017) Prospective association between adherence to the Mediterranean diet and risk of depressive symptoms in the French SU.VI.MAX cohort. Eur J Nutr.

77. Sánchez-Villegas A, Martínez-González MA, Estruch R, Salas-Salvadó J, Corella D, et al. (2013) Mediterranean dietary pattern and depression: the PREDIMED randomized trial. BMC Med 11: 208.

78. Kyrozis A, Psaltopoulou T, Stathopoulos P, Trichopoulos D, Vassilopoulos D, et al. (2009) Dietary lipids and geriatric depression scale score among elders: the EPIC-Greece cohort. J Psychiatr Res 43: 763-769.

79. Logan AC (2005) Omega-3 and depression research: hold the olive oil. Prostaglandins Leukot Essent Fatty Acids 72: 441.

80. Sarris J, Schoendorfer N, Kavanagh DJ (2009) Major depressive disorder and nutritional medicine: a review of monotherapies and adjuvant treatments. Nutr Rev 67: 125-131. 